\title{
Short Communication: Phytochemical screening and toxicity of ethanol extract of Sauropus androgynus
}

\author{
AWALUDIN ${ }^{1, \bullet}$, KARTINA ${ }^{1}$, DIANA MAULIANAWATI ${ }^{1}$, WASMEN MANALU ${ }^{2}$, ANDRIYANTO ${ }^{2}$, \\ RIKA SEPTIANA ${ }^{1}$, AGUS ARFANDI ${ }^{1}$, YUBAL LALANG ${ }^{1}$ \\ ${ }^{1}$ Department of Aquaculture, Faculty of Fisheries and Marine Science, Universitas Borneo Tarakan. Jl. Amal Lama No. 1, North Kalimantan, Indonesia. \\ Tel./fax.+62 1153011775/0551-2052558, ^email: awaludin@borneo.ac.id \\ ${ }^{2}$ Department of Anatomy, Physiology, and Pharmacology, Faculty of Veterinary Medicine, Institut Pertanian Bogor. Jl Agatis, Darmaga Campus, Bogor \\ 16680, West Java, Indonesia
}

Manuscript received: 2 May 2020. Revision accepted: 8 June 2020.

\begin{abstract}
Awaludin, Kartina, Maulianawati D, Manalu W, Andriyanto, Septiana R, Arfandi A, Lalang Y. 2020. Short Communication: Phytochemical screening and toxicity of ethanol extract of Sauropus androgynus. Biodiversitas 21: 2966-2970. Katuk (Sauropus androgynus L.) (SAL) is a plant used to increase the production of breast milk for nursing mothers and lactating mammalian animals because this plant contains high sterols. Phytosterols are plant sterols known to play a role in the synthesis and secretion of progesterone and estradiol. Progesterone and estradiol are hormones that are involved in controlling the reproduction and mammary gland growth and development in mammalian animals. Estradiol also stimulates vitellogenin synthesis in oviparous animals such as avian and fish. The study was designed to determine the phytochemical contents and the level of toxicity of the SAL ethanol extract. The research was conducted in 4 phases i.e., (i) extraction of SAL samples using ethanol 70\%, (ii) the analysis of phytochemical content of SAL extract using GCMS, (iii) toxicity test of SAL extract in giant tiger shrimp larvae, and (iv) data analysis. The results of GCMS analysis showed that the SAL extract was dominated by the fatty acid group (62.92\%), phenol (15.3\%), and terpenoids (4.03\%). These compounds have roles in animal reproduction and production. The mortality data of giant tiger shrimp larvae were analyzed using probit analysis to determine the $\mathrm{LC}_{50}$ of ethanol extract of SAL. The results of toxicity test for 24 hours showed that the $\mathrm{LC}_{50}$ of the ethanol extract of SAL was $552.208 \mathrm{mg} / \mathrm{L}$. The phytochemical analysis showed that SAL extract has dominant concentrations of fatty acid, phenol, and terpenoid that could be used to improve the reproduction and production of fish.
\end{abstract}

Keywords: Penaeus monodon, phytochemical, Sauropus androgynus, toxicity

\section{INTRODUCTION}

The use of plants in various fields has been widely studied. Various chemical compounds in plants can be used to improve reproduction and production in fisheries (Citarasu 2010). One of the beneficial plants found in Indonesia is katuk (Sauropus androgynus L. or SAL). Sauropus androgynus L. is a shrub plant that can be used as a vegetable and this plant grows at an altitude of 5-1.300 meters above sea level. Several studies have analyzed phytochemical contents of SAL. It was reported that SAL contains papaverine with a concentration of $5.8 \mathrm{~g} / \mathrm{kg}$ of fresh leaves (Bender and Ismail 1975) while (Singh et al. 2011) reported that SAL methanolic extracts contained polyphenol (1150.95 mg/100g), Anthocyanin (82.94 $\mathrm{mg} / 100 \mathrm{~g})$, Carotenoid (19.40 mg/100g), Ascorbic acid (314.30 mg/100g), Tannin (88.68 mg/100g), Chlorophyll $(45.60 \mathrm{mg} / 100 \mathrm{~g})$ with high antioxidant activity $(85,63 \%)$. (Agrawal et al. 2014) report that ethanolic extract of $S$. androgynus leaf contains alkaloids, carbohydrates, tannin, protein, sterol, and flavonoids. Suprayogi (2000) found that SAL contained octadecanoic acid, 9-ecosine, 5,8,11heptnearrienoicacid, 9,12,15-octekatrienoicacid, 11,14,17eicosatrienoicacid, androstan-17- one-3-ethyl-3-hydroxy 5- alpha, and 7,3,4-dimethyl-2oxocyclopent-3-enylacetic acid. In addition, SAL leaves have high antioxidant contents (Zuhra et al. 2008).

Sauropus androgynus is a vegetable that can be used medicinally (Andarwulan et al. 2010). S. androgynus leave is well known as a vegetable that has the potential to increase breast milk for nursing mothers. Sa'roni et al. (2004) stated that $S$. androgynus leaves could increase milk production by $50.7 \%$ in nursing mothers. Andarwulan et al. (2012) and Soka et al. (2010) report that consumption of $S$. androgynus can increase milk synthesis and production in lactating women.

Sauropus androgynus leaves contain phytosterols (stigmasterol, sitosterol, and fukosterol) (Subekti 2007). The existence of these compounds is a precursor of androgen and estrogen hormones which are hormones involved in reproduction. Burton and Wells (2002) state that phytoestrogen, one of phytosterols, is a phytochemical in plants that is structurally and functionally similar to $173-$ estradiol. 17ß-estradiol is a signal that stimulates the transcription of vitellogenin gene in the hepatocytes to produce vitellogenin. Vitellogenin is a complex protein used as a precursor of yolk protein for synthesis of yolk contents of the developing oocytes in the oviparous 
animals. In fish, the process of vitellogenesis is started by the synthesis of follicle-stimulating hormone (FSH) by the pituitary gland and its secretion into the blood circulation and induces granulosa cells of developing oocytes to induce the synthesis and secretion of the sex steroid hormone, estrogen (17ß-estradiol), which induces vitellogenin synthesis by the hepatocytes (Hiramatsu et al. 2002).

Suprayogi (2000) reports that androstane-17-one-3ethyl-3-hydroxy 5 alpha, which is contained in SAL serves as a precursor in the synthesis of steroid hormones (progesterone, estradiol, testosterone, and glucocorticoids), so that sheep fed ration mixed with SAL can increase milk production. Therefore, the addition of $S$. androgynus leaf extract to the feed is also expected to stimulate fish reproduction to increase fisheries production. The addition of natural products in animal feed to increase production has been widely investigated. In animal production, the use of natural products is more beneficial than synthetic compounds because it is easily degraded in the body and has low side effects.

The toxicity of SAL extract was measured using the Brine Shrimp Lethality Test (BSLT) (Meyer et al. 1982). Lethal Concentration Test $\left(\mathrm{LC}_{50}\right)$ used tiger shrimp larvae (Penaeus monodon). Testing of $\mathrm{LC}_{50}$ was conducted to determine the toxicity of a natural product. Testing of $\mathrm{LC}_{50}$ on tiger shrimp larvae is the first step to determine the level of toxicity of SAL ethanol extract. Plant toxicity is usually tested using rats, but the cost is expensive and torturing animals so this study used shrimp larvae (Parra et al. 2001). The use of BSLT in toxicity testing of plants also gives a significant result (Kamba and Hassan 2010).

This study was designed to determine the phytochemical contents of SAL extracts using ethanol solvents. Information on $\mathrm{LC}_{50}$ of SAL ethanol extract on tiger shrimp is required as a basis for consideration of the supplementation of $S$. androgynus extract in feed to increase fisheries production. Phytochemicals contents of SAL extracts are important to know so that information can be used to explore compounds having biological roles in increasing fisheries production. Toxicity tests were carried out to prevent adverse effects and to explain toxic effects and determine safety limits in relation to the use of a compound and the ability to inhibit protein denaturation (Madhu et al. 2014). Yunita et al. (2013) reported that SAL from different places has different levels of toxicity and this condition is presumably due to the secondary metabolism contents. To date, there are few studies that have investigated the phytochemical of SAL extract and this study is basic research to support the study of SAL extract supplementation in fish for the development of aquaculture by using natural materials.

\section{MATERIALS AND METHODS}

\section{Materials}

Sauropus androgynus leaves were collected from a farm in Tarakan, North Kalimantan Province, Indonesia. The leaves were extracted with $70 \%$ ethanol and tested for toxicity with tiger shrimp larvae.

\section{Sauropus androgynus leaves extraction}

Fresh leaves from S. androgynus plants were cleaned and dried at $24^{\circ} \mathrm{C}$ about 7 days. The dried plants were then powdered on size 60 mesh particle material. The powdered plants were extracted using the maceration method with $70 \%$ ethanol (Merck, 1:3 w/v). The simplicia were blended and soaked with ethanol for 3-4 days, then the extract was filtered using filter papers Whatman no. 1 and the filtrate was concentrated by evaporated using a rotary evaporator $\left(60^{\circ} \mathrm{C}\right)$ to separate the extract from the solvent.

\section{Phytochemicals analysis of Sauropus androgynus leaves extract}

Sauropus androgynus extract compounds were identified using Gas Chromatography-Mass Spectrometry (GC-MS) with oven temperature conditions $\left(50^{\circ} \mathrm{C}-290^{\circ} \mathrm{C}\right)$, Interface $0\left(290^{\circ} \mathrm{C}\right)$, control mode (split), pressure $(20.8$ psi), total flow $(23.7 \mathrm{ml}) / \mathrm{min}$ ), split ratio: (200: 1), split flow (199 ml/min), gas (He), and detector (MSD). GCMS testing was carried out at the Forensic Laboratory of Mabes Polri, Jakarta.

\section{Toxicity test of ethanol extract of Sauropus androgynus leaves}

One thousand of tiger shrimp larvae (PL 12 stage) were prepared and acclimatized for 3 days. S. androgynus-leaves extracts were made with concentrations of $0 \mathrm{mg} / \mathrm{L}, 10$ $\mathrm{mg} / \mathrm{L}, 100 \mathrm{mg} / \mathrm{L}, 300 \mathrm{mg} / \mathrm{L}, 500 \mathrm{mg} / \mathrm{L}$, and $1000 \mathrm{mg} / \mathrm{L}$. Twenty tiger shrimp larvae were put into a container that had previously added SAL extract with a total volume of $200 \mathrm{~mL}$. For each treatment, five repetitions were made. After 24 hours, the number of mortality and surviving shrimps from each container were counted. The mortality of tiger shrimp was calculated by the following equation (1). The data obtained were calculated by probit analysis method using SPSS 21 to determine $\mathrm{LC}_{50}$, then incorporated into the equation.

$$
\mathrm{Y}=\mathrm{a}+\mathrm{bX}
$$

Where; $\mathrm{Y}=50$, and the $\mathrm{X}$ value showed $\mathrm{LC}_{50}$.

\section{RESULTS AND DISCUSSION}

\section{Phytochemical of ethanol extract of Sauropus androgynus}

The yield of SAL leaves is presented in Table 1. The yield value is a comparison between extract obtained with the extracted simplicial. The yield of SAL extract obtained from the extraction results with ethanol solvent was $24.42 \%$. The yield value obtained in this study was higher compared to the $11.56 \%$ yield reported by using $96 \%$ ethanol (Mustarichie et al. 2019). The greater yield produced, the more efficient was the extraction method used. The number of yields obtained is thought to be influenced by the use of polar ethanol solvents so that they can attract compounds in the SAL which are mostly polar compounds. Zhao and Zhang (2014a) reported that different solvents would dissolve different compounds 
depending on their levels of polarity. According to Zhao and Zhang (2014b), ethanol solvent has a greater dielectric constant (24.30) so that it can attract more secondary metabolites.

Separation of phytochemical compounds using gas chromatography method analysis is a key factor in the analysis of unknown plant chemical components (Revathi et al. 2015). GC-MS analysis has been widely used in identifying hundreds of components of compounds found in plant cells that cannot be done by ordinary phytochemical screening. This limitation is due to the limitation of phytochemical screening to the identification of compound groups (Hamuel 2012). Phytochemical compounds in plants have been widely identified and applied in various fields of research both fisheries, agriculture, health, and other fields of sciences. The phytochemical test showed the presence of certain phytocomponents as were presented in Table 2.

Based on the results of analysis with GC-MS it was obtained 17 chemical compounds with different percentages areas (Table 2). According to Andarwulan et al. (2010), compounds that are commonly found in plants and responsible for antioxidant activities are phenols $(1,49$ mg GAE//g fw) and these compounds are found in SAL leaves. The most dominant peaks (Table 2) seen from the percentage of successive areas were 9,12,15Octadecatrienoic acid (28.89\%) and methyl ester and hexadecenoic acid $(25,89 \%)$ which were a group of fatty acid compounds. According to Tvrzicka et al. (2011), each type of fatty acid has different physiological and biological effects on health. Octadecatrienoic acid (PUFA) is a precursor of a group of hormone-like compounds namely prostaglandin, prostacyclin, thromboxane, and leukotriene. These compounds play a role in regulating blood pressure, heart rate, immune function, nervous system stimulation, muscle contraction, and wound healing (Moussa and Almaghrabi 2015). Improvements in pregnancy when cows were fed Ca salts of a mix of C18:2 omega- 6 and transoctadecenoic fatty acids were supported by the increased fertilization and embryo quality in non-super ovulated lactating dairy cows (Cerri et al. 2004). Supplementation of $S$. androgynus powder at a dose of about $3 \%$ can increase reproductive hormones in female kacang goat (Putranto et al. 2017).

Another fatty acid compound found in the SAL extract was linoleic acid (5.25\%). Linoleic acid is one of the essential fatty acids. Essential fatty acids cannot be formed in the body and must be supplied directly in the food. Essential fatty acids are important components of a diet because the body cannot synthesize them. Therefore, humans must obtain linoleic acid from food. Linoleic acid is a precursor of arachidonic acid which can be converted into many biologically active molecules (Taha et al. 2017).

Some phenol compounds such as 2H-1-Benzopyran-6ol, y-Tocopherol, and Vitamin E dl- $\alpha$-Tocopherol are found in SAL leaves extract. Phenol compounds are important in plant physiology because they play roles in pigmentation, taste, for growth, reproduction, and for plant resistance to pathogens and predators (Adeboye et al. 2014). Vitamin E is the major lipid-soluble component in the cell antioxidant defense system and is exclusively obtained from the diet. It has numerous important roles within the body because of its antioxidant activity.

Table 1. Yield of SAL leaves using maceration method

\begin{tabular}{lccc}
\hline Sample & Simplicia $(\mathbf{g})$ & Extract $(\mathbf{g})$ & Yield $(\boldsymbol{\%})$ \\
\hline SAL leaves & 1638 & 400 & 24.42 \\
\hline
\end{tabular}

Table 2. Phytochemical compounds of SAL using GC/MS

\begin{tabular}{clccl}
\hline $\begin{array}{c}\text { Retention } \\
\text { time }\end{array}$ & Metabolite group & RI & $\begin{array}{c}\text { Relative } \\
\text { area }(\%)\end{array}$ & \multicolumn{1}{c}{ Constituent } \\
\hline 7.671 & Fatty acid & 195479 & 2.01 & Tetradecanoic acid, ethyl ester \\
9.021 & Fatty acid & 231394 & 25.89 & Hexadecanoic acid, ethyl ester, ethyl palmitate \\
9.774 & Terpenoid (ditherpene) & 245670 & 4.03 & Phytol \\
10.064 & Fatty acid & 258928 & 5.25 & Linoleic acid ethyl ester \\
10.141 & Fatty acid (omega-3) & 240840 & 28.89 & 9,12,15-Octadecatrienoic acid, methyl ester \\
10.201 & Fatty acid & 263346 & 0.88 & Octadecanoic acid, ethyl ester (CAS) \\
14.262 & Isoprenoid (phenol) & 333929 & 9.94 & 2H-1-Benzopyran-6-ol, \\
14.894 & Phenol & 341263 & 3.92 & Gamma-Tocopherol \\
15.433 & Phenol & 347589 & 1.44 & Vitamin E dl-.alpha-tocopherol \\
18.288 & Cyclopropane & 109458 & 1.41 & Ethyl chrysanthemumate, cyclopropanecarboxylic acid \\
18.784 & Sterol & 351444 & 1.13 & 9,19-Cyclolanostan-3-ol \\
19.665 & Sterol & 337917 & 0.94 & 23-Ethylcholesta-5,23,28-trien-3.beta-ol \\
20.083 & Aromatic heterocyclic & 265956 & 1.21 & 1-(6-Fluoro-benzothiazol-2-yl)-3,4-dimethyl-pyrano(2,3- \\
& & & & c)pyrazol-6(1H)-one \\
20.613 & Enones (toluenes) & 151019 & 2.33 & 3-Buten-2-one, 4-(4-hydroxy-2,2,6- trimethyl-7- \\
& & & & oxabicyclo[4.1.0]hept-1-yl)- \\
21.853 & Catechols & 246538 & 1.28 & 3',5'-diphenylcyclohexa-2,5-dienes piro-2'-(2'H-pyrrol)-4-one; 1- \\
& & & & Az aspiro[4.5]deca-1,3,6,9 tetraen-8-one, 2,4-diphenyl- (CAS) \\
22.605 & Coumarin & 245150 & 7.93 & 7-hydroxyphenprocoumon \\
23.417 & Aromatic hidrocarbon & 342134 & 1.51 & 2,5-Pyrrolidinedione \\
& & & & \\
\hline
\end{tabular}




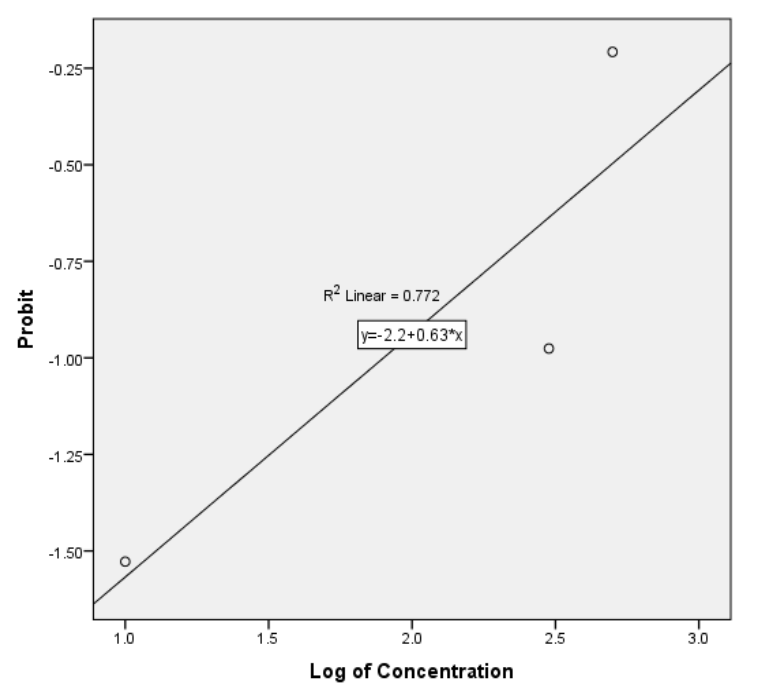

Figure 1. Log concentration ethanol extract of Sauropus androgynus

The terpenoid compound, phytol, was also found in SAL leaves extract with an area percentage of $4.03 \%$. Phytol, diterpene alcohol produced from chlorophyll, is a food additive and an aromatic ingredient. Phytol is a chemical compound that functions as precursors of tocopherols (vitamin E) and phylloquinone/vitamin $\mathrm{K}$ (Almeida et al. 2016). Phytol also plays a role in the synthesis of vitamins $\mathrm{E}$ and K1. Given its role in the synthesis of vitamin $\mathrm{E}$ and $\mathrm{K} 1$ it is likely that this compound can act as an antimicrobial. Rupa et al. (2017) report that terpenoids compounds play roles in the healing process of wound or infection and antibacterial agents.

The dominance of fatty acid group compounds with a total percentage area of $62.92 \%$ in SAL leaves extract has important and potential roles in the application of these compounds in the field of aquaculture, in terms of improving reproductive performances of fish and crustaceans. This dominant content of fatty acid groups in SAL extract is because fatty acids are the constituents of cell membranes and act as ingredients in the formation of hormones involved in reproduction. Therefore, before further application is carried out, the first step is the toxicity testing of SAL leaves extract on shrimp larvae (P.monodon). This test was done to determine the safe dosage of SAL extract to be applied in the feed with the aim of increasing reproductive performance.

\section{Toxicity activity analysis}

Toxicity tests were carried out as a preliminary test in the use of natural materials. This test is related to the concentration of natural ingredients that will be used. $\mathrm{LD}_{50}$ test is not done on humans, but uses animals that the dose of LD50 found can be used to calculate LD50 in humans (Maheshwari and Shaikh 2016). The compounds tested in this study were $S$. androgynus leaves extracted using ethanol. In this study, the animals used for toxicity tests were tiger shrimp larvae, because it is easier to do when compared to using mice. The results of the study showed that the concentration of extract in the media could cause the mortality of tiger shrimp in a row with concentrations of $0,10,100,300,500$, and $1000 \mathrm{mg} / \mathrm{l}$. Variations in the concentration of $S$. androgynus leaves extract in this experiment showed different effects on the mortality of tiger shrimp larvae. The results of toxicity test of ethanol extract of SAL leaves showed that the higher the concentration of ethanol extract of SAL leaves the greater the mortality rate of tiger shrimp larvae (Figure 1). This result is in line with the results of Putri et al. (2012) which state that the higher the concentration of the extract the higher the mortality rate of Artemia uramiana larvae. The result of toxicity test is basic information for selecting doses for long-term toxicity studies and other studies involving the use of animals (Maheshwari and Shaikh 2016).

BSLT is a method used to determine the toxicity of a compound. This method is simple, easy to do, cheap, fast, and requires a small amount of extract (Pisutthanan et al. 2004). Mirzaei and Mirzaei (2013) reported BSLT testing to measure the toxicity of medicinal plants using Artemia uramiana was more responsive in detecting toxicity. Therefore, in this study, the modified of BSLT test has been done by using tiger shrimp larvae as test animals. Acute toxicity evaluates side effects that occur after an organism has been exposed to a harmful compound in a short time (Saganuwa 2016. From the data in Table 4, it is apparent that the higher the concentration, the higher the level of toxicity of $S$. androgynus extract. The total mortality was obtained by summing the mortality larvae at each concentration. Therefore this extract is relatively safe for consumption by humans and livestock as a source of feed or another function. The results of the probit analysis using SPSS showed the $\mathrm{LC}_{50}$ value of $S$. androgynus leaf extract was $552.208 \mathrm{mg} / \mathrm{L}$. Meyer et al. (1982) report that the level of toxicity of a compound in a toxicity test is that if the extract can cause $50 \%$ mortality of animals tested. Awaludin et al. (2019) reported the toxicity was directly proportional to the concentration of extract, the higher the concentration of extract, the higher the mortality. The result found in this study showed that SAL leaves extract had low toxicity. Therefore, the SAL leaves extract is safe and can be used as a natural material to improve reproduction process. The mechanism of larvae mortality observed in this test was probably related to the presence of cannibalism because during calculating the survival larvae, it was found that there were only a few larvae with intact heads.

\section{ACKNOWLEDGEMENTS}

This experiment was funded by the Indonesian Ministry of Research, Technology and Higher Education (Kemenristekdikti) through the scheme Penelitian Kerjasama Antar Perguruan Tinggi (PKPT), year 2019. 


\section{REFERENCES}

Adeboye PT, Bettiga M, Olsson L, 2014. The chemical nature of phenolic compounds determines their toxicity and induces distinct physiological responses in Saccharomyces cerevisiae in lignocellulose hydrolysates. AMB Express 4: 46. DOI: 10.1186/s13568-014-0046-7.

Agrawal SK, Karthikeyan V, Parthiban P, Nandhini R. 2014. Multivitamin plant: Pharmacognostical standardization and phytochemical profile of its leaves. J Pharm Res 88: 910-915.

Almeida J, Azevedo M da S, Spicher L, Glauser G, vom Dorp K, Guyer L, del Valle Carranza A, Asis R, de Souza AP, Buckeridge M, Demarco D, Bres C, Rothan C, Peres LEP, Hörtensteiner S, Kessler F, Dörmann P, Carrari F, Rossi M. 2016. Down-regulation of tomato phytol kinase strongly impairs tocopherol biosynthesis and affects prenyl lipid metabolism in an organ-specific manner. J Exp Bot 67 919-934. DOI: 10.1093/jxb/erv504.

Andarwulan N, Batari R, Sandrasari DA, Bolling B, Wijaya H. 2010. Flavonoid content and antioxidant activity of vegetables from Indonesia. Food Chem 121: 1231-1235.

Andarwulan N, Kurniasih D, Apriady RA, Rahmat H, Roto AV, Bolling BW. 2012. Polyphenols, carotenoids, and ascorbic acid in underutilized medicinal vegetables. J Funct Foods 4: 339-347. DOI: 10.1016/j.jff.2012.01.003.

Awaludin A, Yulma Y, Kartina K. 2019. Identification of secondary metabolites from ethanol extract of ciplukan (Physalis angulate) leaves and toxicity test on post-larvae of tiger shrimp (Penaeus monodon). Jurnal Ilmu Perikanan dan Kelautan 11: 92. DOI: 10.20473/jipk.v11i2.13162.

Bender AE, Ismail KS. 1975. Nutritive value and toxicity of a Malaysian food, Sauropus albicans. Plant Foods Man 1: 139-143. DOI 10.1080/03062686.1975.11904165.

Burton JL, Wells M. 2002. The effect of phytoestrogens on the female genital tract. J Clin Pathol 55: 401-407.

Cerri RLA, Bruno RGS, Chebel RC, Galva KN, Rutgliano H, Juchem SO, Thatcher WW, Luchini D, Santos JEP. 2004. Effect of fat sources differing in fatty acid profi le on fertilization rate and embryo quality in lactating dairy cows. J Dairy Sci 87 (1): 297. (Abstr.)

Citarasu T. 2010. Herbal biomedicines: A new opportunity for aquaculture industry. Aquacult Intl 18: 403-414.

Hamuel J. 2012. Phytochemicals: Extraction methods, basic structures and mode of action as potential chemotherapeutic agents, in: Rao V. (Ed.), Phytochemicals - A global perspective of their role in nutrition and health. InTech, Rijeka, Croatia. DOI: 10.5772/26052

Hiramatsu N, Cheek AO, Sullivan CV, Matsubara T, Hara A. 2005. Vitellogenesis and endocrine disruption. In: Mommsen TP, Moon TW (eds) Biochemistry and Molecular Biology of Fishes. Elsevier Science, Amsterdam.

Kamba AS, Hassan LG. 2010. Antibacterial screening and brine shrimp (Artemia salina) toxicity of Securidaca longepedunculata (Polygalaceae) Root Bark. Afr J Pharmaceut Sci Pharm 1 (1): 85-95.

Madhu CS, Manukumar HMG, Basavaraju P. 2014. New-vista in finding antioxidant and anti-inflammatory property of crude protein extract from Sauropus androgynus leaf. Acta Sci Pol Technol Aliment 13. DOI: $10.17306 / \mathrm{J} . A F S .2014 .4 .4$.

Maheshwari DG, Shaikh NK. 2016. An overview of toxicity testing method. Intl J Pharm Technol 8 (2): 3834-3849.

Meyer B, Ferrigni N, Putnam J, Jacobsen L, Nichols D, McLaughlin J, 1982. Brine shrimp: A convenient general bioassay for active plant constituents. Planta Med 45: 31-34.

Mirzaei M, Mirzaei AR. 2013. Comparison of the Artemia salina and Artemia uramiana bioassays for toxicity of 4 Iranian medicinal plants. Intl Res J Biol Sci 2: 49-54.

Moussa TAA, Almaghrabi OA. 2015. Fatty acid constituents of Peganum harmala plant using gas chromatography-mass spectroscopy. Saudi J Biol Sci 23: 397-403.
Mustarichie R, Salsabila T, Iskandar Y. 2019. Determination of the major component of water fraction of katuk (Sauropus androgynous (L) Merr.) leaves by liquid chromatography-mass spectrometry. J Pharm Bioall Sci 11 (4): 611-618.

Parra AL, Yhebra RS, Sardiñas IG, Buela LI. 2001. Comparative study of the assay of Artemia salina L. and the estimate of the medium lethal dose (LD50 value) in mice, to determine oral acute toxicity of plant extracts. Phytomed 8 (5): 395-400.

Pisutthanan S, Plianbangchang P, Pisutthanan N, Ruanruay S, Muanrit O. 2004. Brine shrimp lethality activity of Thai medicinal plants in the Family Meliaceae. Naresuan Univ J 12 (2): 13-18.

Putranto HD, Hasibuan GP, Yumiati Y, Ginting SM. 2017. Effect of katuk (Sauropus androgynus) powder supplementation on the levels of progesterone (P4) and estradiol-17 $\beta$ (E2) hormones in kacang goat (Capra aegragus). Nusantara Biosci 9 (1): 86-91.

Putri MKD, Pringgenies D, Radjasa OK. 2012. Uji fitokimia dan toksisitas ekstrak kasar gastropoda (Telescopium telescopium) terhadap larva Artemia salina. J Mar Res 1: 58-66.

Revathi P, Jeyaseelansenthinath $\mathrm{T}$, Thirumalaikolundhusubramaian $\mathrm{P}$. 2015. Preliminary phytochemical screening and GC-MS analysis of ethanolic extract of mangrove plant Bruguiera cylindrica (Rhizho) L. Intl J Pharmacog Phytochem Res 6 (4): 729-740.

Rupa D, Sulistyaningsih Y, Dorly D, Ratnadewi D. 2017. Identification of secretory structure, histochemistry, and phytochemical compounds of medicinal plant Hyptis capitata Jacq. Biotropia 24. DOI: 10.11598/btb.2017.24.2.499

Sa'roni S, Sadjiman T, Sja'bani M, Zulaela Z. 2004. Effectiveness of the Sauropus Androgynus (L.) Merr leaf extract in increasing mother's breast milk production. Media Penelitian dan Pengembangan Kesehatan 14: 20-24.

Saganuwa SA. 2016. Toxicity study of drugs and chemicals in animals: An overview. Bulgarian J Vet Med 20 (4): 291-318.

Singh S, Singh DR, Salim KM, Srivastava A, Singh LB, Srivastava C, 2011. Estimation of proximate composition, micronutrients and phytochemical compounds in traditional vegetables from Andaman and Nicobar Islands. Intl J Food Sci Nutr 62: 765-773.

Soka S, Alam H, Boenjamin N, Agustina TW, Suhartono MT. 2010. Effect of Sauropus androgynus leaf extracts on the expression of prolactin and oxytocin genes in lactating BALB/C mice. J Nutr Nutr 3: $31-36$.

Subekti S. 2007. Sterols component of katuk leaves extract (Sauropus androgynus) and its relation to japanese quail reproduction system. [Dissertation]. IPB University, Bogor. [Indonesian]

Suprayogi A. 2000. Studies on the biological effets of Sauropus androgynus (L.) Merr: Effects on milk production and the possibilities of induced pulmonary disorder in lactating sheep. Cuviller Verlag, Gottingen, Germany.

Taha AY, Blanchard HC, Cheon Y, Ramadan E, Chen M, Chang L, Rapoport SI. 2017. Dietary linoleic acid-lowering reduces the lipopolysaccharide-induced increase in brain arachidonic acid metabolism. Mol Neurobiol 54: 4303-4315.

Tvrzicka E, Kremmyda LS, Stankova B, Zak A. 2011. Fatty acids as biocompounds: Their role in human metabolism, health and disease A review. Part 1: Classification, dietary sources and biological functions. Biomed Pap 155: 117-130.

Yunita O, Yuwono M, Rantam FA. 2013. In vitro cytotoxicity assay of Sauropus androgynus on human mesenchymal stem cells. Toxicol Environ Chem 95: 679-686.

Zhao S, Zhang D. 2014a. An experimental investigation into the solubility of Moringa oleifera oil in supercritical carbon dioxide. J Food Eng 138: 1-10. DOI: 10.1016/j.jfoodeng.2014.03.031

Zhao S, Zhang D. 2014b. Supercritical CO2 extraction of Eucalyptus leaves oil and comparison with soxhlet extraction and hydrodistillation methods. Sep Purif Technol 133: 443-451.

Zuhra CF, Tarigan JB, Sihotang H. 2008. Aktivitas antioksidan senyawa flavonoid dari daun katuk (Sauropus androgunus (L) Merr.). Jurnal Biologi Sumatra 3: 7-10. 